\title{
Suitable Site Selection of Decentralised Treatment Plants Using Multicriteria Approach in GIS
}

\author{
K. Deepa, M. Krishnaveni \\ Center for Water Resources, Anna University, Chennai, India \\ Email: deepa_deebha@yahoo.co.in,mkveni@annauniv.edu \\ Received March 10, 2012; revised March 29, 2012; accepted April 11, 2012
}

\begin{abstract}
Metropolitan cities like Chennai facing rapid urbanisation. This results in informal extension of cities in peri-urban and rural areas. Once the city expands the problem arising is the water supply and sewage treatment system. In the present work an attempt is made in site suitable selection of Decentralised treatment plants (DCTP) with appropriate waste water treatment technologies using GIS techniques. Multicriteria analysis were performed by the combination of Analytical Hierarchy Process (AHP). Six thematic maps were considered such as population density map, landuse map, slope map, soil map, cost map and technology. Different classes were identified for each thematic maps. Using Analytical Hierarchy Principle (AHP) [1] (Saaty, 2000), a paired comparison matrix was prepared for criteria classes and individual class weights and map scores were worked out. These weights were applied in linear summation equation to obtain a unified weight map containing due weights of all input variables. Finally all the weighted maps were reclassified to arrive the best suitable site location of decentralised treatment plants.
\end{abstract}

Keywords: GIS; Analytical Hierarchy Process; Wastewater; Reuse; Multicriteria

\section{Introduction}

Water plays an important role in the development of any activity in the world. A good management of water and waste water resources uplift any country or region status a higher in the aspects of health and economy. For the future decades the cost of investment will be implemented in treatment of wastewater by choosing low cost sewage treatment technology. [2] Looker (1998) also recommend that for ecological wastewater treatment closed-loop treatment system must be used as when compared with the present day linear disposal system. [3] Rose (1999) states that the development of ecological wastewater management helps to attain high environmental quality, high yields in food and fiber, low consumption, good quality, high efficiency production and full utilization of wastes. The problem with the current treatment technologies is they lack sustainability. The conventional centralized system flushes pathogenic bacteria out of the residential area, using large amounts of water and often combines the domestic wastewater with rainwater, causing the flow of large volumes of pathogenic wastewater [4] Sarah Volkman (2003). On the other hand Decentralized Wastewater Treatment Systems is a technical, effective, efficient and affordable approach for rural and urban households in developing countries, [5] Er. Ajit Seshadri (1999). The site selection of small wastewater treatment systems depends on many technical, environmental and socio economic factors. The site selection of such crucial analysis can be successfully achieved by decision analysis tool used in Geographical Information System. Analytic Hierarchy Process (AHP) is a widely used method in decision-making. AHP is introduced by [6] Saaty (1972), with the basic assumption that comparison of two elements is derived from their relative importance. The decision-making in AHP is a continuous process starting from analysing the decision environment to understand and arrange the criteria into different groups and levels till evaluating the criteria in its decision outputs [1]. Saaty (2000) developed pair wise comparison matrix inorder to perform any difficult task in a simpler manner. [7] Anagnostopoulos KP (2007) performed GIS based on support decision system in evaluation of wastewater treatment process by selection of environmental, economic and social criteria. Fuzzy extension of AHP was applied in site suitable process of wastewater treatment.

\section{Study Area}

The study area lies between $80^{\circ} 9^{\prime} 12^{\prime \prime} \mathrm{E}$ to $80^{\circ} 16^{\prime} 9^{\prime \prime} \mathrm{E}$ longitudes and $12^{\circ} 51^{\prime} 20^{\prime \prime} \mathrm{N}$ to $12^{\circ} 58^{\prime} 19^{\prime \prime} \mathrm{N}$ latitudes of Survey of India Toposheet No 66D 1\&5, covers an area of $118 \mathrm{sq} \cdot \mathrm{km}$ of Sholinganallur Administrative boundary of South Chennai City (Figure 1). The study area consist of 19 town panchayats and 4 village panchayats. The 


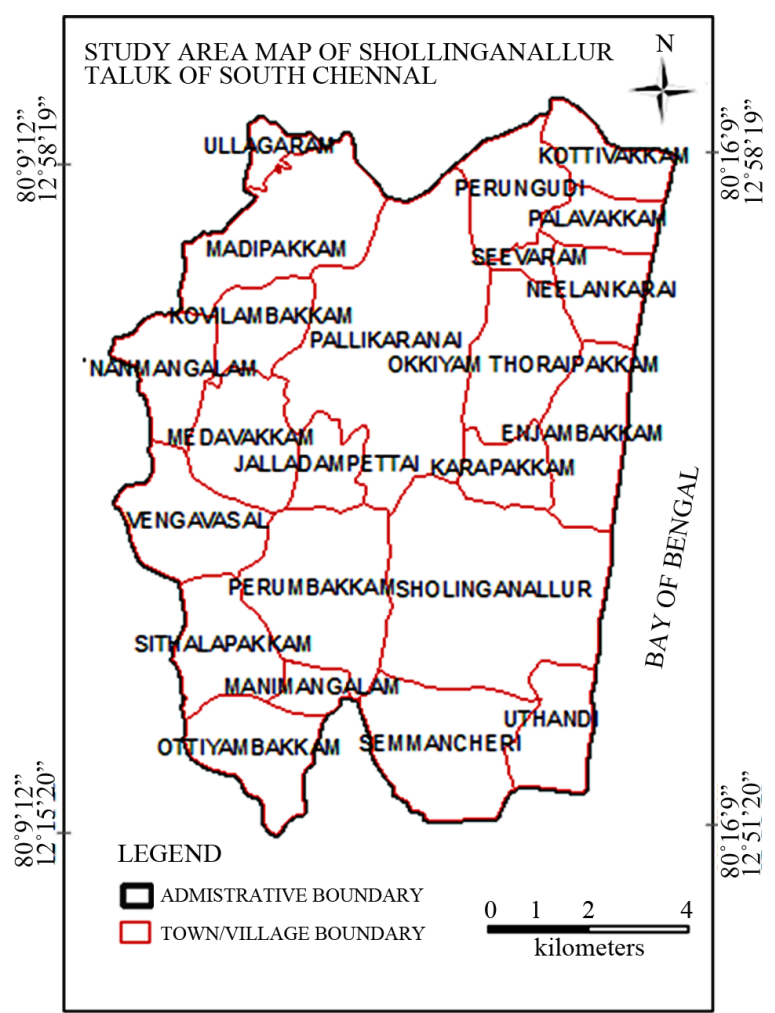

Figure 1. Study area map of Shollinganallur Administrative Boundary.

population density of south Chennai is 13451, the number has witnessed a tremendous growth in its manufacturing, retail, health care and IT sector in the last 10 years. South Chennai has become an important destination trade and tourism in recent years. It has evoked as a city with tremendous potential for industrial growth because of its economic viability and available infrastructure. Major types of soils exist in the study area are the Beach sands, Clay \& alluvial and Soils. Major water bearing formations are Sand, sandstone, weathered and fractured granites, gneisses and Charnockite. The study area receives the Average Annual Rainfall of $1200 \mathrm{~mm}$. The temperature is usually in the range of $13.9^{\circ} \mathrm{C}$ to $45^{\circ} \mathrm{C}$.

\section{Methodology}

Six thematic layers were selected for determination of suitable site selection of decentralised wastewater treatment plants. They are: Landuse (Land availability), Population density, Soil, Slope, cost and technology. Different classes were identified for each criterion and these were arranged in decreasing order of weight. Using Analytical Hierarchy Principle (AHP) [8] (Saaty, 1980), a paired comparison matrix was prepared for the seven criteria for the study area and individual class weights (rank) and map scores (weight) were worked out. These weights were applied in linear summation equation to obtain a unified weight map containing due weights of all input variables, which will be further reclassified to arrive a suitable area map. The fundamental principle of the analysis is the possibility of connecting information, based on knowledge, to make decisions or previsions; the knowledge can be taken from experience or derived from the application of other tools. The analysis is based on three fundamental principles namely breaking down the problem, pair wise comparison of the various alternatives, synthesis of the preferences. The "principle of breaking down" consists in subdividing the problem into simple clusters that are represented by different levels in a hierarchal structure. The decomposition is carried out from the top to the bottom, starting from the objective, to the criteria and sub-criteria, to the final alternatives. The "principle of pair wise comparison" consists in giving a rate to each cluster to measure the importance of each level in the hierarchy. Each single element is evaluated using a pair wise comparison [9] (Sandeep Goyal et al.). The comparisons are made on a 9-point scale, the socalled "fundamental scale of Saaty", Table 1, where,

$\mathrm{n}=$ No. of criteria assigned (example: Landuse, slope, Soil, Population, Cost and Techology)

$\lambda_{\max }=$ Maximum value of eign vector

$\mathrm{CI}=$ Consistency index calculated as follows:

$$
\mathrm{CI}=\frac{\left(\lambda_{\max }-n\right)}{(n-1)}
$$

$\mathrm{CR}=$ Consistency Ratio $(<0.1$, the criterion priority considered are satisfying) calculated as follows:

$$
\mathrm{CR}=\frac{\mathrm{CI}}{\mathrm{RI}}
$$

$\mathrm{RI}=$ Random Index value refered from the Satty (2000) matrix Table 2.

A AHP model (Figure 2) was developed using Visual Basic 6.0 to calculate the eign values and weights of the different criteria.

Table 1. Rating scale used in [1] Saaty's (2000) AHP model.

\begin{tabular}{ll}
\hline Weight & Definition \\
\hline 1 & Equally likely occurrence \\
3 & Moderately likely occurrence \\
5 & Strongly likely occurrence \\
7 & Very strongly likely occurrence \\
9 & Extremely strongly likely occurrence \\
The values 2, 4, 6 and 8 can be used to denote intermediary values \\
\hline
\end{tabular}

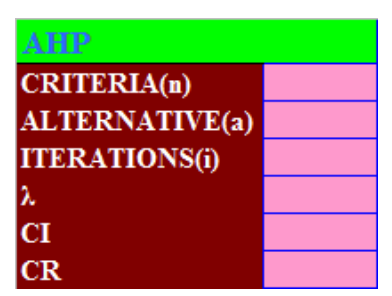

Figure 2. AHP model. 
Table 2. Random Index value refered from the [8] Satty (1980).

\begin{tabular}{|c|c|c|c|c|c|c|c|c|c|c|}
\hline Matrix size (n) & 1 & 2 & 3 & 4 & 5 & 6 & 7 & 8 & 9 & 10 \\
\hline Randomized Index (RI) & 0 & 0 & 0.58 & 0.90 & 1.12 & 1.24 & 1.32 & 1.41 & 1.45 & 1.49 \\
\hline
\end{tabular}

\section{Criterion Layering}

1) Landuse: Landuse classifications in the study were prepared by using Cartosat satellite imagery in Arcgis 9.3. (Figure 3).

2) Slope: Decentralised treatment system should be constructed in low slope to get good gradual flow of wastewater collection and to avoid over land flow during rainy seasons. Slope layer was obtained from Shuttle Radar Topography Mission Digital Elevation Model (SRTM DEM) 90 m-resolution (Figures 4 and 5).

3) Population Density map: Population data and number of households data were collected for study area by ward and village wise from Directorate of Census department, Chennai (2001).

Point layer map was prepared the projected population for 30 years values were given as input to the corresponding point id. The projected population data's were interpolated using natural neighbour interpolation techniques to arrive the projected population density map of the study area (Figure 6).

4) Soil map: Soil map was collected from Institute of Remote sensing with 1:50,000 scale of Survey of India toposheet 66D1\&5 (Figure 7).

5) Cost: Four cost criteria options were considered.

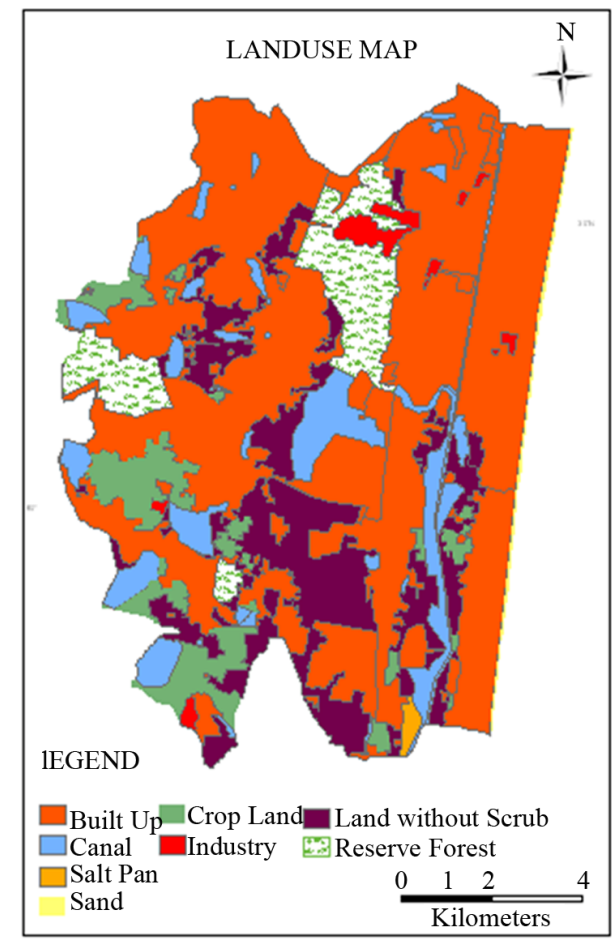

Figure 3. Landuse map.

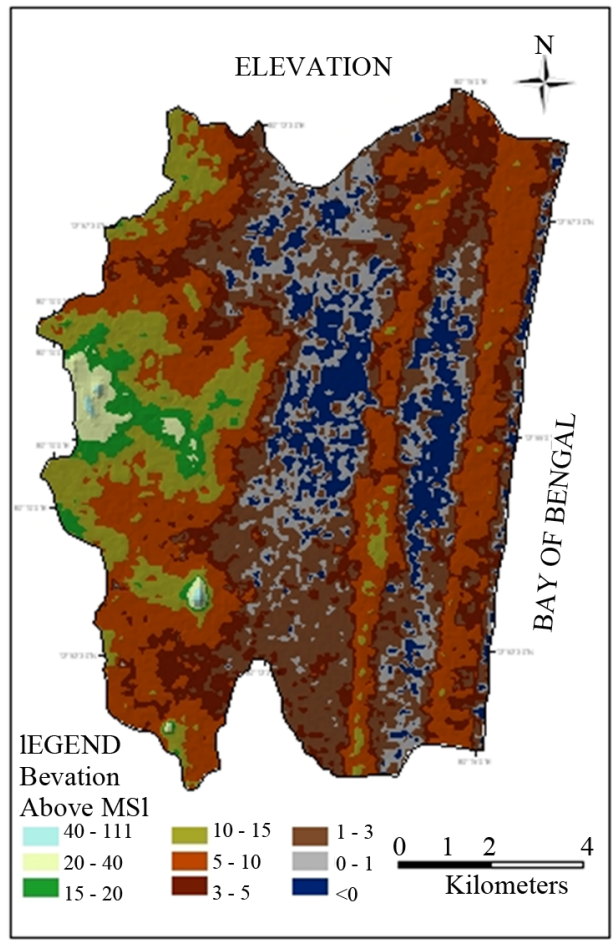

Figure 4. Digital elevation model.

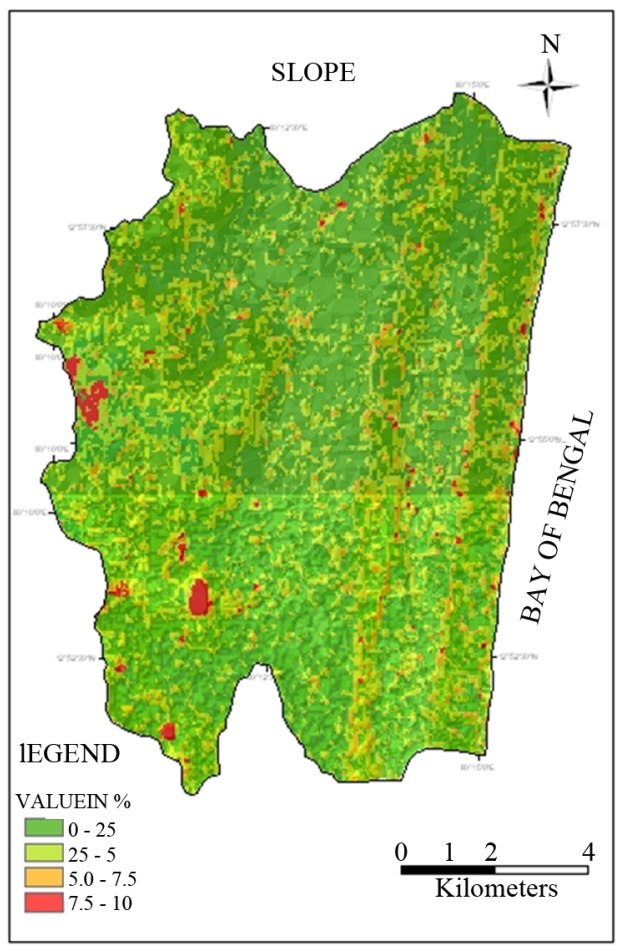

Figure 5. Slope map. 


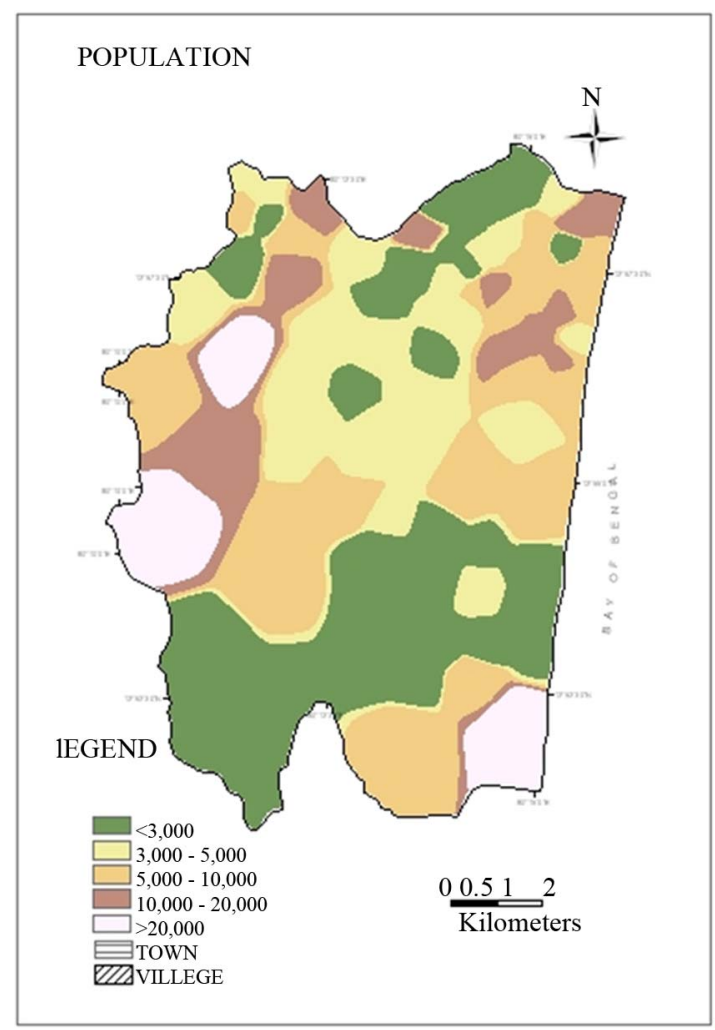

Figure 6. Population density map.

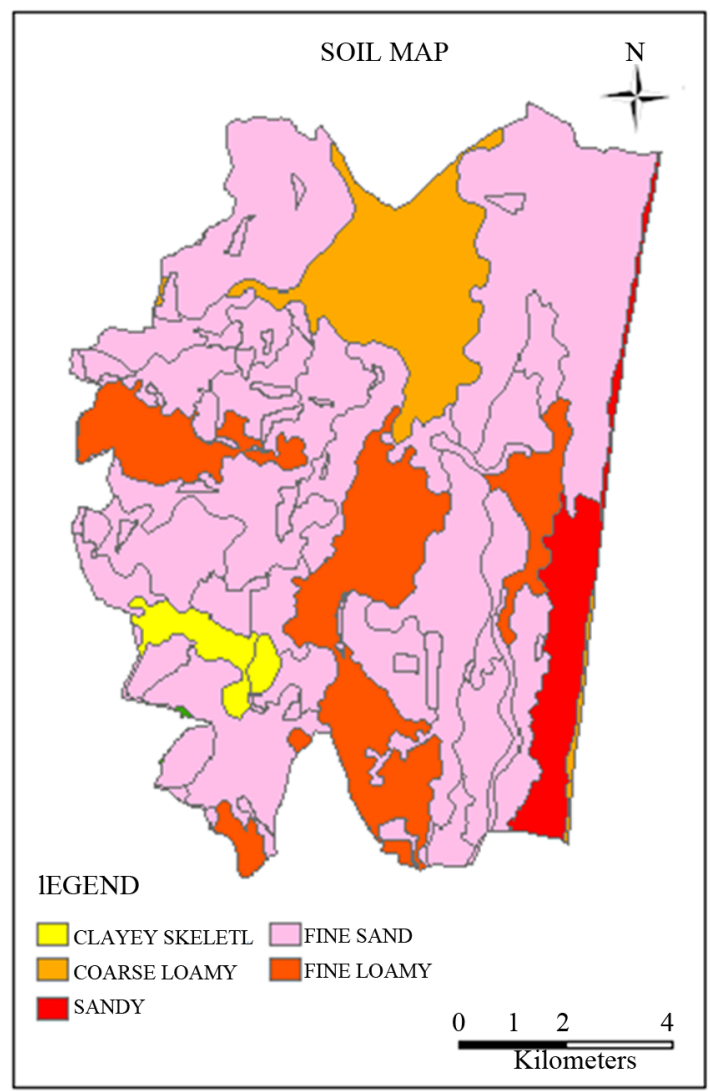

Figure 7. Soil map.
The first is the distance from households to DCTP minimise pipes length and corresponding costs, and the second the difference in elevation between settlements area's and DCTPs, which reflects related costs for wastewater pumping, the third is the construction and maintenance cost and fourth option is the land cost.

6) Technology: Selection of technology involves fours option namely land association, land parcel size, quality of wastewater and temperature. Based on the above four class two types of DCTP is a) Upflow Anaerobic Sluge Blanket which is highly suitable for urban area's with all type of water quality; b) Constructed wetlands is suitable for rural level where the waste water quality should meet the soil conditions.

\section{Results and Discussion}

\subsection{Suitable Site Selection Using AHP}

Decentralised treatments system selection is based upon terrain characteristic along with soil, land use and other parameters. These thematic information are generated through GIS software for the site selection evaluation. In order to achieve the objective it is essential to systematiccally organise the database and check out every possibility of inter-thematic and interclass dependencies and variability operating in nature. In the present study an attempt has been made to use Multi Criteria Evaluation technique to evaluate the interclass and intermap dependencies for selection DCTP. The individual class weights and map scores were determined through this technique. These weights were applied in linear summation equation to obtain a unified weight map containing due weights of all input variables, which was further reclassified to arrive a best suitable sites for DCTP. Using Analytical Hierarchy Principle (AHP) [6] (Saaty, 2000), a paired comparison matrix was prepared for the six criteria for the study area of Shollinganallur revenue taluk and individual class weights and map scores were worked out. The paired comparison matrix was prepared for each criterion using Saaty's nine point scale. All the criteria are not equally important, every criteria will contribute towards the suitability at different degrees. The relative degree of contribution of various criteria can be addressed well when they are grouped into various groups and organised at various hierarchies. Relative importance of the criteria parameters can be well evaluated to determine the suitability by multi-criteria evaluation techniques. Six thematic layers-population density map, landuse map, slope map, soil map, cost map and technology mentioned above were selected for the purpose of the work. Individual class weights (rank) and map scores (weight) were given as follows.

\subsection{Thematic Layers}

Pairwise comparison matrix developed by [8] Saaty 
(1980) explained in the Section 2 was applied in obtaining the relative weights of each criterion to find the best suitable site for Decentralised Treatment Plants in the study area (Table 3).

\subsection{Cumulative Suitability Index-Potential DCTP Area}

The themes (Tables 4-9) which represent the influence of environmental factors like population density map, landuse map, slope map, soil map, cost map and technology were added using the Union intersect operation under weighted Overlay operation of Analysis tool.

Finally CSI was calculated using the formula Sum [weights $*$ ranks] for every factor.

CSI $=[(0.26 *$ Landuse rank $)+(0.26 *$ Slope rank $)+$ $(0.26 *$ Population rank $)+(0.09 *$ Soil rank $)+(0.09 *$ Cost rank $)+(0.05 *$ Technology rank $)]$

The percentage of suitable land available for Decentra-

Table 3. Main criterion weight scores.

\begin{tabular}{|c|c|c|c|c|c|c|c|}
\hline Criterions & Landuse & Slope & Population & Soil & Cost & Technology & Weights \\
\hline Landuse & 1 & 1 & 1 & 3 & 3 & 5 & 0.26 \\
\hline Slope & 1 & 1 & 1 & 3 & 3 & 5 & 0.26 \\
\hline Population & 1 & 2 & 1 & 3 & 3 & 5 & 0.26 \\
\hline Soil & $1 / 3$ & $1 / 3$ & $1 / 3$ & 1 & 1 & 3 & 0.09 \\
\hline Cost & 0.33 & 0.33 & 0.33 & 1 & 1 & 3 & 0.09 \\
\hline Technology & 0.2 & 0.2 & 0.2 & $1 / 3$ & 0.33 & 1 & 0.05 \\
\hline
\end{tabular}

$\lambda_{\max }=6.0, \mathrm{CI}=0.011, \mathrm{CR}=0.9 \%$.

Table 4. Sub class criterion landuse.

\begin{tabular}{cccccccc}
\hline Criterions & Vacant Land & Scrub Land & Water Logged & Crop Land & Water Bodies & Build Up land & Weights \\
\hline Vacant Land & 1 & 1 & 1 & 4 & 6 & 6 & 0.27 \\
Scrub Land & 1 & 1 & 1 & 4 & 6 & 6 & 0.27 \\
Water Logged & 1 & 1 & 1 & 4 & 6 & 6 & 0.27 \\
Crop Land & $1 / 4$ & $1 / 4$ & $1 / 4$ & 1 & 6 & 5 & 0.08 \\
Water Bodies & 0.16 & 0.16 & 0.16 & 1 & 1 & 5 & 0.07 \\
Build Up Land & 0.16 & 0.16 & 0.16 & $1 / 5$ & $1 / 5$ & 0.03 \\
\hline
\end{tabular}

$\lambda_{\text {max }}=6.3, \mathrm{CI}=0.062, \mathrm{CR}=5.0 \%$.

Table 5. Sub class criterion slope.

\begin{tabular}{ccccc}
\hline & Gentle & Moderate & Steep & Weights \\
\hline Gentle & 1 & 2 & 3 & 0.5 \\
Moderate & $1 / 2$ & 1 & 1 & 0.25 \\
Steep & $1 / 3$ & 1 & 1 & 0.25 \\
\hline
\end{tabular}

$\lambda_{\max }=3.02, \mathrm{CI}=0.011, \mathrm{CR}=1.9 \%$.

Table 6. Sub class criterion population.

\begin{tabular}{ccccc}
\hline & High & Moderate & Low & Weights \\
\hline High & 1 & 2 & 4 & 0.57 \\
Moderate & $1 / 2$ & 1 & 2 & 0.29 \\
Low & $1 / 3$ & 1 & 1 & 0.14 \\
\hline
\end{tabular}

High $=8000$ population size, Moderate $=5000$, Low $<=3000, \lambda_{\max }=3.02, \mathrm{CI}=0, \mathrm{CR}=\%$. 
Table 7. Sub class criterion soil.

\begin{tabular}{cccccc}
\hline Class & Sandy & Silty Sand & Sandy Silt & Clay & Weight \\
\hline Sandy & 1 & 2 & 2 & 3 & 0.375 \\
Silty Sand & $1 / 2$ & 1 & 2 & 3 & 0.375 \\
Sandy Silt & $1 / 2$ & $1 / 2$ & 1 & 1 & 0.125 \\
Clay & $1 / 3$ & $1 / 3$ & 1 & 1 & 0.125 \\
\hline
\end{tabular}

$\lambda_{\max }=4, \mathrm{CI}=0, \mathrm{CR}=0 \%$.

Table 8. Sub class criterion technology.

\begin{tabular}{|c|c|c|c|c|c|}
\hline Class & $\begin{array}{c}\text { Land } \\
\text { Association } \\
\text { (Urban/Village) }\end{array}$ & $\begin{array}{l}\text { Land } \\
\text { Parcel } \\
\text { Size }\end{array}$ & $\begin{array}{c}\text { Quality of } \\
\text { Wastewater }\end{array}$ & Temperature & Weights \\
\hline $\begin{array}{c}\text { Land } \\
\text { Association } \\
\text { (Urban/ } \\
\text { Village) }\end{array}$ & 1 & 1 & 1 & 1 & 0.2 \\
\hline $\begin{array}{l}\text { Land Parcel } \\
\text { Size }\end{array}$ & 1 & 1 & 2 & 2 & 0.4 \\
\hline $\begin{array}{l}\text { Quality of } \\
\text { Wastewater }\end{array}$ & 1 & $1 / 2$ & 1 & 1 & 0.2 \\
\hline Temperature & 1 & $1 / 2$ & 1 & 1 & 0.2 \\
\hline
\end{tabular}

$\lambda_{\max }=4, \mathrm{CI}=0, \mathrm{CR}=0 \%$.

Table 9. Sub class criterion cost.

\begin{tabular}{|c|c|c|c|c|c|}
\hline Class & $\begin{array}{l}\text { Distance } \\
\text { from the } \\
\text { households }\end{array}$ & $\begin{array}{l}\text { Difference } \\
\quad \text { in } \\
\text { Elevation }\end{array}$ & $\begin{array}{l}\text { Construction, } \\
\text { Transportation, } \\
\text { Operation and } \\
\text { Maintenance } \\
\text { Cost }\end{array}$ & $\begin{array}{l}\text { Land } \\
\text { Cost }\end{array}$ & Weight \\
\hline $\begin{array}{l}\text { Distance from } \\
\text { the households }\end{array}$ & 1 & 2 & 2 & 3 & 0.43 \\
\hline $\begin{array}{l}\text { Difference in } \\
\text { Elevation }\end{array}$ & $1 / 2$ & 1 & 2 & 3 & 0.27 \\
\hline $\begin{array}{c}\text { Construction, } \\
\text { Transportation, } \\
\text { Operation and } \\
\text { Maintenance } \\
\text { Cost }\end{array}$ & $1 / 2$ & $1 / 2$ & 1 & 2 & 0.19 \\
\hline Land Cost & $1 / 3$ & $1 / 3$ & $1 / 2$ & 1 & 0.11 \\
\hline
\end{tabular}

lised Treatment Plants were given in Table 10.

\section{Conclusion}

Rural, periurban and urban should focus in future for decentralised wastewater treatment systems. The cluster of decentralised treatment system provide best management of wastewater in summer and winter seasons. The investment, operation and maintenance of decentralised
Table 10. The percentage of land availability for suitable site of Decentralised Treatment Plants (DCTP) were listed below.

\begin{tabular}{cccc}
\hline SI. No & Potential Sites & Area (sq.km) & Area (\%) \\
\hline 1 & High potential & 23.4 & 21.707 \\
2 & Moderate potential & 33.3 & 30.89 \\
3 & Low potential & 51.1 & 47.40 \\
\hline
\end{tabular}

treatment plants will provide a higher level of environment. Integration of GIS and AHP provides best decision tool in selecting appropriate decentralised treatment systems in appropriate site. Six criteria were selected such as landuse, slope, population, soil, cost and technology. A paired comparison matrix was prepared for criteria classes and individual class weights and map scores were worked out. These weights were applied in linear summation equation to obtain a unified weight map containing due weights of all input variables. Finally all the weighted maps were reclassified to arrive the best potential site location of decentralised treatment plants.

\section{Acknowledgements}

Authors sincerely thanks for financial funding supported by UGC, New Delhi for carrying out the research outcome during the study carried by the research scholar.

\section{REFERENCES}

[1] T. L. Saaty, "How to Make a Decision: The Analytic Hierarchy Process," European Journal of Operational Research, Vol. 48, No. 1, 2000, pp. 9-26. doi:10.1016/0377-2217(90)90057-I

[2] N. Looker, "Municipal Wastewater Management in Latin America and the Caribbean,” R. J. Burnside International Limited, Published for Roundtable on Municipal Water for the Canadian Environment Industry Association, 1998.

[3] G. D. Rose, "Community-Based Technologies for Domestic Wastewater Treatment and Reuse: Options for Urban Agriculture,” N.C. Division of Pollution Prevention and Environmental Assistance, CFP Report Series: Report 27, 1999.

[4] S. Volkman, "Sustainable Wastewater Treatment and Reuse in Urban Areas of the Developing World,” A Field Engineering in the Developing World Report, 2003.

[5] A. Seshadri, "Decentralized Wastewater ManagementAn Overview of Community Initiatives," The Vigyan Vijay Foundation, New Delhi, 2004.

[6] T. L. Saaty, "Priorities and Hierarchies: Eigenvalue Structure,” Working Paper, University of Pennsylvania, 1972.

[7] K. P. Anagnostopoulos and A. P. Vavatsikos, "GIS and Multicriteria Decision Support Systems: A Review," Journal of European Water, Vol. 19/20, 2007, pp. 15-24.

[8] T. L. Saaty, “The Analytic Hierarchy Process,” McGraw- 
Hill, New York, 1980.

[9] S. Goyal, R. S. Bharadwaj and D. K. Jugran, "Multi Cri- teria Analysis Using GIS for Ground Water Resource Evaluation in Rawasen and Pili Watershed,” UP, 1999. 